\title{
Effects of a controlled-release fertilizer on yield, nutrient uptake, and fertilizer usage efficiency in early ripening rapeseed (Brassica napus L.)*
}

\author{
Chang TIAN ${ }^{\S 1}$, Xuan ZHOU ${ }^{\S 2}$, Qiang LIU ${ }^{1}$, Jian-wei PENG ${ }^{1}$, Wen-ming WANG ${ }^{1}$, \\ Zhen-hua ZHANG ${ }^{1}$, Yong YANG ${ }^{1}$, Hai-xing SONG $^{\dagger 1}$, Chun-yun GUAN ${ }^{3}$ \\ $\left({ }^{1}\right.$ College of Resources and Environment, Hunan Agricultural University / Hunan Provincial Key Laboratory of Farmland Pollution Control and \\ Agricultural Resources Use / Hunan Provincial Key Laboratory of Plant Nutrition in Common University / National Engineering \\ Laboratory of College of Resources and Environment, Southern Regional Collaborative Innovation Center for \\ Grain and Oil Crops in China, Changsha 410128, China) \\ $\left({ }^{2}\right.$ College of Environmental Science and Resources, Zhejiang University, Hangzhou 310058, China) \\ $\left({ }^{3}\right.$ National Center of Oilseed Crops Improvement, Hunan Branch, Changsha 410128, China) \\ 'E-mail: shx723@126.com \\ Received Sept. 8, 2015; Revision accepted Dec. 27, 2015; Crosschecked Sept. 10, 2016
}

\begin{abstract}
Background: Nitrogen $(\mathrm{N})$, phosphorous $(\mathrm{P})$, and potassium $(\mathrm{K})$ are critical nutrient elements necessary for crop plant growth and development. However, excessive inputs will lead to inefficient usage and cause excessive nutrient losses in the field environment, and also adversely affect the soil, water and air quality, human health, and biodiversity. Methods: Field experiments were conducted to study the effects of controlled-release fertilizer (CRF) on seed yield, plant growth, nutrient uptake, and fertilizer usage efficiency for early ripening rapeseed (Xiangzayou 1613) in the red-yellow soil of southern China during 2011-2013. It was grown using a soluble fertilizer (SF) and the same amounts of CRF, such as SF1/CRF1 (3750 kg/hm $\left.{ }^{2}\right)$, SF2/CRF2 (3000 kg/hm²), SF3/CRF3 (2250 kg/hm $\left.{ }^{2}\right)$, SF4/CRF4 $\left(1500 \mathrm{~kg} / \mathrm{hm}^{2}\right)$, SF5/CRF5 $\left(750 \mathrm{~kg} / \mathrm{hm}^{2}\right)$, and also using no fertilizer (CK). Results: CRF gave higher seed yields than SF in both seasons by $14.51 \%$. CRF4 and SF3 in each group achieved maximum seed yield $\left(2066.97\right.$ and $1844.50 \mathrm{~kg} / \mathrm{hm}^{2}$, respectively), followed by CRF3 $\left(1929.97 \mathrm{~kg} / \mathrm{hm}^{2}\right)$ and SF4 $\left(1839.40 \mathrm{~kg} / \mathrm{hm}^{2}\right)$. There were no significant differences in seed yield among CK, SF1, and CRF1 (P>0.05). CRF4 had the highest profit $\left(7126.4 \mathrm{CNY} / \mathrm{hm}^{2}\right)$ and showed an increase of $12.37 \%$ in seed yield, and it decreased by $11.01 \%$ in unit fertilizer rate compared with SF4. The branch number, pod number, and dry matter weight compared with SF increased significantly under the fertilization of CRF $(P<0.05)$. The pod number per plant was the major contributor to seed yield. On the other hand, the $\mathrm{N}, \mathrm{P}$, and $\mathrm{K}$ uptakes increased at first and then decreased with increasing the fertilizer rate at maturity, and the N, P, and K usage efficiency decreased with increasing the fertilizer rate. The N, P, and $K$ uptakes and usage efficiencies of the CRF were significantly higher than those of SF $(P<0.05)$. The $\mathrm{N}$ accumulation and $\mathrm{N}$ usage efficiency of CRF increased by an average of $13.66 \%$ and 9.74 percentage points, respectively, compared to SF. In conclusion, CRF significantly promoted the growth of rapeseed with using total $\mathrm{N}$ as the base fertilizer, by providing sufficient $\mathrm{N}$ in the later growth stages, and last by reducing the residual $\mathrm{N}$ in the soil and increasing the $\mathrm{N}$ accumulation and $\mathrm{N}$ usage efficiency.
\end{abstract}

Key words: Early ripening rapeseed, Controlled-release fertilizer, Yield, Nutrient uptake, Fertilizer usage efficiency http://dx.doi.org/10.1631/jzus.B1500216

CLC number: S145.6; S565.4

\footnotetext{
Corresponding author

$\S$ The two authors contributed equally to this work

* Project supported by the National Natural Science Foundation of China (No. 31372310), the Youth Fund of Orient Science and Technology College of Hunan Agricultural University (No. 14QNZ09), the Cultivation Physiology Station of National Technical System in Rapeseed Industry (No. CARS-13), and the National Key Technology R \& D Program of China (Nos. 2012BAD15B04, 2014BAC09B01-01, and 2014BAD14B01) (D) ORCID: Xuan ZHOU, http://orcid.org/0000-0003-0209-5165

(C) Zhejiang University and Springer-Verlag Berlin Heidelberg 2016
} 


\section{Introduction}

Nitrogen $(\mathrm{N})$, phosphorous $(\mathrm{P})$, and potassium (K) are critical nutrient elements for crop plant growth and development, and applying fertilizers, especially $\mathrm{N}$ to crops, is a valuable agronomic practice (Zhao et al., 2013). However, excessive fertilization can result in nutrient inefficiencies and excessive losses of $\mathrm{N}$ and $\mathrm{P}$ in the field environment, and also impact soil, water and air quality, human health, and biodiversity (Goulding et al., 2008). Nitrate nitrogen $\left(\mathrm{NO}_{3}{ }^{-}-\mathrm{N}\right)$ contaminations of both the soil and water are caused by over usage of fertilizers especially $\mathrm{N}$, and large $\mathrm{NO}_{3}{ }^{-} \mathrm{N}$ accumulation can reduce the $\mathrm{N}$ usage efficiency (NUE) of crops (Zhu and Chen, 2002; Ju et al., 2004). Also, excessive usage of different fertilizers, especially N, can increase lodging, causing a reduction in the yield and quality of the crops (Ozer, 2003). Therefore, interventions to increase fertilizer usage efficiency (FUE) and reduce nutrient inputs, especially $\mathrm{N}$, are of significant importance for reducing environmental loading and lowering the costs of agricultural production (Wang et al., 2011).

Controlled-release fertilizer (CRF) is a good alternative to soluble fertilizer (SF) to increase FUE and minimize nutrient losses, especially $\mathrm{N}$, in the field environment (Zhao et al., 2013). The coating material types of CRF play a key role in gradually releasing the nutrient (Li et al., 2012), and the most important parameters for controlling nutrient release include the thickness of the coating membrane, followed by temperature, granule radius, soil microbial activity, etc. (Du et al., 2008; Kaplan et al., 2013), and they are controlled to match the nutrient requirement of the plants (Dai et al., 2008; Yan et al., 2008; Ni et al., 2009). Due to a lack of experience with the field performance of CRF and its high relative cost, current grower acceptance is limited (Zhao et al., 2013). However, the greatest benefits of changing from SF to CRF include not only increased profitability, but also reductions in the environmental pollution of crop production. In some countries, it has primarily been applied to nursery stock (Azeem et al., 2014), and there have been few investigations in the field on the performance of crops grown with CRF (Noellsch et al., 2009).

Rapeseed (Brassica napus L.) is an important agricultural crop cultivated for its oil, which can be used as an edible product or for various industrial applications (Malagoli et al., 2005a; 2005b). As one of the major economic crops in China, rapeseed provides more than $40 \%$ of the plant oil produced, with about half of the available cropping area being used for rapeseed crops (Wang et al., 2013; Hussain et al., 2014). Along with the acceleration of rural urbanization, farmer employment, and non-agricultural production, there has been a large decline in both the quantity and quality of labor engaged in agricultural production in China, to some extent restricting the development of rapeseed production (Guan, 2006). Under the current environment, the establishment of the CRF method is more important in improving rapeseed production and increasing the edible oil supply in China. Despite its high capacity to remove nitrate from the soil, rapeseed is characterized by a very low $\mathrm{N}$ recovery in the reproductive tissues under field conditions (Malagoli et al., 2005a). There currently are no published research data on the fertilizer rate of CRF response to early ripening rapeseed in southern China.

The objectives of this study are: (1) to estimate N, $\mathrm{P}$, and $\mathrm{K}$ responses for rapeseed performances at maturity, including seed yield, yield components, and nutrient accumulation; (2) to investigate the effects of CRF on the developmental dynamics of nutrient uptake during the growing season, in terms of dry matter production, nutrient translocation, and $\mathrm{N}, \mathrm{P}$, and $\mathrm{K}$ usage efficiencies; and (3) to choose a reasonable application rate of CRF for rapeseed in the region. Our results could help increase the understanding of nutrient development dynamics and seed yield responses for CRF, and provide some suggestions to improve the nutrient management of rapeseed by light and simple fertilization.

\section{Materials and methods}

\subsection{Experimental design}

In connection with early ripening rapeseed testing, Xiangzayou 1613 (provided by the Hunan Branch of National Center for Oil Modified) planting was done on a farm in Huilongpu Town, Ningxiang Country, Hunan Province in China $\left(23^{\circ} 21^{\prime} \mathrm{N}, 112^{\circ} 46^{\prime} \mathrm{E}\right)$. The soil, classified as a red-yellow soil and evolved from the red earth platform of the quaternary period, 
was considered to be highly suitable for crop production The soil $\mathrm{pH}$ was 6.1 . The average organic matter content in the tillage layer was $48.89 \mathrm{~g} / \mathrm{kg}$, the available N, P, K, and boron (B) were 169.16, 15.43, 59.08 , and $0.31 \mathrm{mg} / \mathrm{kg}$, respectively and the total $\mathrm{N}, \mathrm{P}$, and $\mathrm{K}$ were $2.73,0.54$, and $16.38 \mathrm{~g} / \mathrm{kg}$, respectively.

The methods of soil analysis were referenced from Soil and Agricultural Chemistry Analysis written by Bao (2005). CRF, a coated compound fertilizer was offered by the Hunan Xingxiang Biological Science and Technology Co., Ltd., Xiangtan City, Hunan Province, China and was used in the experiment, with SF being used as a control. The contents of $\mathrm{N}$, phosphorus pentoxide $\left(\mathrm{P}_{2} \mathrm{O}_{5}\right)$, and potassium oxide $\left(\mathrm{K}_{2} \mathrm{O}\right)$ in each SF and CRF were $12 \%, 6 \%$, and $7 \%$, respectively, with the boric fertilizer being $15 \mathrm{~kg} / \mathrm{hm}^{2}$ (B, 10.8\%).

Field experiments were conducted during 20112013 as a random complete block design with three replications. The area of each plot was $20 \mathrm{~m}^{2}$. There were eleven treatments (Table 1), as SF1/CRF1 $\left(3750 \mathrm{~kg} / \mathrm{hm}^{2}\right), \mathrm{SF} 2 / \mathrm{CRF} 2\left(3000 \mathrm{~kg} / \mathrm{hm}^{2}\right), \mathrm{SF} 3 / \mathrm{CRF} 3$ $\left(2250 \mathrm{~kg} / \mathrm{hm}^{2}\right), \mathrm{SF} 4 / \mathrm{CRF} 4\left(1500 \mathrm{~kg} / \mathrm{hm}^{2}\right), \mathrm{SF} 5 / \mathrm{CRF} 5$ $\left(750 \mathrm{~kg} / \mathrm{hm}^{2}\right)$, and CK (no fertilizer). All fertilizers were applied at a basal dosage. Direct seeding of rapeseed was performed in October, 2011/2012. After the emergence of seedlings, the density was thinned to $37.5 \times 10^{4}$ plants $/ \mathrm{hm}^{2}$ by 2 times, and the harvest time was in May, 2012/2013. Herbicides were not applied to the field experiment and weeds were controlled with hand weeding. Field management, in general, was the same as with the rapeseed field.

Table $1 \mathrm{~N}, \mathrm{P}_{2} \mathrm{O}_{5}, \mathrm{~K}_{2} \mathrm{O}$, and $\mathrm{B}$ dosages of early ripening rapeseed using different fertilizer treatments

\begin{tabular}{crrrc}
\hline \multirow{2}{*}{ Treatment } & \multicolumn{4}{c}{ Dosage $\left(\mathrm{kg} / \mathrm{hm}^{2}\right)$} \\
\cline { 2 - 5 } & $\mathrm{N}$ & \multicolumn{1}{c}{$\mathrm{P}_{2} \mathrm{O}_{5}$} & \multicolumn{1}{c}{$\mathrm{K}_{2} \mathrm{O}$} & $\mathrm{B}$ \\
\hline $\mathrm{CK}$ & 0 & \multicolumn{1}{c}{0} & \multicolumn{1}{c}{0} & 0 \\
$\mathrm{SF} 1 / \mathrm{CRF} 1$ & 450.0 & 225.0 & 262.5 & 1.6 \\
$\mathrm{SF} 2 / \mathrm{CRF} 2$ & 360.0 & 180.0 & 210.0 & 1.6 \\
$\mathrm{SF} 3 / \mathrm{CRF} 3$ & 270.0 & 135.0 & 157.5 & 1.6 \\
$\mathrm{SF} 4 / \mathrm{CRF} 4$ & 180.0 & 90.0 & 105.0 & 1.6 \\
$\mathrm{SF} 5 / \mathrm{CRF} 5$ & 90.0 & 45.0 & 52.5 & 1.6 \\
\hline
\end{tabular}

\subsection{Plant sampling and $\mathrm{N}, \mathrm{P}$ and $\mathrm{K}$ content determination}

To measure the $\mathrm{N}, \mathrm{P}$, and $\mathrm{K}$ uptakes of the aboveground, five plants were collected for treatment in the wintering period, flowering stage, and harvest time, respectively. At maturity, five plants were manually harvested for treatment. The branch number per plant, pod number per plant, and seed number per pod were counted. Drying and weighing the harvest were measured to the community order production. The aboveground dry matter was determined by oven-drying the samples at $80{ }^{\circ} \mathrm{C}$ until a constant weight was achieved. Then the dry matter weight and 1000-seed weight were determined. Subsequently, samples were manually separated into the vegetative and seed portions. The seeds and straw were ground using a cyclone sample mill with a mesh size of $0.5 \mathrm{~mm}$. Then the seed and straw $\mathrm{N}, \mathrm{P}$, and $\mathrm{K}$ concentrations were measured using the Kjeldahl method, vanadium-molybdenum-yellow photometric method and flame spectrophotometer method, respectively. Seed oil content was determined by using a Soxhlet apparatus. The following parameters were calculated (Dordas, 2009): (1) N, P, and K accumulation $\left(\mathrm{kg} / \mathrm{hm}^{2}\right)=$ $\mathrm{N}, \mathrm{P}$, and $\mathrm{K}$ content $(\%) \times$ dry matter accumulation $\left(\mathrm{kg} / \mathrm{hm}^{2}\right)$; (2) $\mathrm{N}, \mathrm{P}$, and $\mathrm{K}$ translocation amount $\left(\mathrm{kg} / \mathrm{hm}^{2}\right)=\mathrm{N}, \mathrm{P}, \mathrm{K}$ accumulation of straw at the flowering stage $\left(\mathrm{kg} / \mathrm{hm}^{2}\right)-\mathrm{N}, \mathrm{P}$, and $\mathrm{K}$ accumulation of straw at maturity $\left(\mathrm{kg} / \mathrm{hm}^{2}\right)$; (3) $\mathrm{N}, \mathrm{P}$, and $\mathrm{K}$ translocation rate $(\%)=\mathrm{N}, \mathrm{P}$, and $\mathrm{K}$ translocation amount $\left(\mathrm{kg} / \mathrm{hm}^{2}\right) / \mathrm{N}, \mathrm{P}$, and $\mathrm{K}$ accumulation at the flowering stage $\left(\mathrm{kg} / \mathrm{hm}^{2}\right) \times 100 \%$; (4) N, P, and K contribution rate $(\%)=\mathrm{N}, \mathrm{P}$, and $\mathrm{K}$ translocation amount $\left(\mathrm{kg} / \mathrm{hm}^{2}\right)$ / $\mathrm{N}, \mathrm{P}$, and $\mathrm{K}$ accumulation of seed at maturity $\left(\mathrm{kg} / \mathrm{hm}^{2}\right) \times$ $100 \% ;(5) \mathrm{N}, \mathrm{P}$, and $\mathrm{K}$ usage efficiency $(\%)=(\mathrm{N}, \mathrm{P}$, and $\mathrm{K}$ accumulation $\left(\mathrm{kg} / \mathrm{hm}^{2}\right)-\mathrm{N}, \mathrm{P}$, and $\mathrm{K}$ accumulation at the $\mathrm{CK}$ area $\left.\left(\mathrm{kg} / \mathrm{hm}^{2}\right)\right) / \mathrm{N}, \mathrm{P}$, and $\mathrm{K}$ fertilizer rate $\left(\mathrm{kg} / \mathrm{hm}^{2}\right) \times 100 \%$; (6) $\mathrm{N}, \mathrm{P}$, and $\mathrm{K}$ harvest index $(\%)=$ $\mathrm{N}, \mathrm{P}$, and $\mathrm{K}$ accumulation of seed at maturity $\left(\mathrm{kg} / \mathrm{hm}^{2}\right) /$ $\mathrm{N}, \mathrm{P}$, and $\mathrm{K}$ accumulation of aboveground at maturity $\left(\mathrm{kg} / \mathrm{hm}^{2}\right) \times 100 \%$; and (7) seed profit $\left(\mathrm{CNY} / \mathrm{hm}^{2}\right)=$ seed yield $\left(\mathrm{kg} / \mathrm{hm}^{2}\right) \times$ quarter price $(\mathrm{CNY} / \mathrm{kg})-$ fertilizer rate $\left(\mathrm{kg} / \mathrm{hm}^{2}\right) \times$ quarter price $(\mathrm{CNY} / \mathrm{kg})$, with the quarter price of seed yield being $4.50 \mathrm{CNY} / \mathrm{kg}, \mathrm{CRF} 1.45 \mathrm{CNY} / \mathrm{kg}$, and SF $1.40 \mathrm{CNY} / \mathrm{kg}$.

\subsection{Statistical analysis}

Statistical analyses were performed using the analysis of the variance (ANOVA) in the general linear model procedure of SPSS (Ver. 11, SPSS, Chicago, IL, USA). Results are presented as the mean of the two seasons of the experimentation, because the 
trends of these parameters were consistent between seasons. The least significant differences (LSDs) between the means were estimated at the $95 \%$ confidence level. Unless indicated otherwise, significant differences among different plants are given at $P<0.05$; the LSD was used to compare adjacent means arranged in order of magnitude.

\section{Results}

\subsection{Seed yield and seed profit}

As shown in Table 2, seed yield was significantly affected by fertilization treatments $(P<0.05)$, and CRF had higher seed yield than SF by an average of $17.33 \%$, with a lower fertilizer rate per $\mathrm{kg}$ yield by an average of $14.20 \%$. CRF4 achieved maximum yield $\left(2066.97 \mathrm{~kg} / \mathrm{hm}^{2}\right)$, and the lowest was observed in SF1 $\left(664.63 \mathrm{~kg} / \mathrm{hm}^{2}\right)$. SF2, SF3, SF4, and SF5 were higher in seed yield than CK by $63.5 \%, 160.2 \%$, $159.5 \%$, and $113.6 \%$, respectively. In addition, CRF1, CRF2, CRF3, CRF4, and CRF5 were higher in seed yield than CK by $25.9 \%, 89.9 \%, 172.2 \%, 191.6 \%$, and $154.5 \%$, respectively. CRF4 and CRF5 greatly reduced the $\mathrm{N}$ input, while further increasing more yield production. Thus, CRF provides a strategy for environmentally sustainable increases in seed yield.

Seed yield output minus the fertilizer input represents the net profit for each treatment. The average net profits of SF1 to SF5 were -2259.2, 1017.0, 5150.3, 6177.3, and 5762.7 CNY/hm ${ }^{2}$, respectively, and the average net profits of CRF1 to CRF5 were $-1420.5,1709.1,5422.4,7126.4$, and $7033.1 \mathrm{CNY} / \mathrm{hm}^{2}$, respectively. Due to excessive fertilizer use, SF1 and CRF1 had negative profits and higher profits were achieved in SF4, SF5, CRF4, and CRF5. Compared with SF4 and SF5, the profits of CRF4 and CRF5 increased by 949.1 and $1270.4 \mathrm{CNY} / \mathrm{hm}^{2}$, respectively. CRF4 as the optimum treatment achieved the best yield $\left(2066.97 \mathrm{~kg} / \mathrm{hm}^{2}\right)$ with a fertilizer rate of $1500 \mathrm{~kg} / \mathrm{hm}^{2}$, for a net profit of $7126.4 \mathrm{CNY} / \mathrm{hm}^{2}$.

Taking the fertilizer rates ( $X_{1}$ for SF, $X_{2}$ for CRF) as the independent variables and seed yields ( $Y_{1}$ for $\mathrm{SF}, Y_{2}$ for $\mathrm{CRF}$ ) as the dependent variables, the correlation analysis of the two-year experiment was performed to establish regression equations of fertilizer rates on seed yields as shown below (Fig. 1):

SF: $Y_{1}=-0.00033 X_{1}^{2}+1.2061 X_{1}+752.49, R^{2}=0.9580$; CRF: $Y_{2}=-0.00035 X_{2}^{2}+1.3025 X_{2}+838.08, R^{2}=0.9210$.

The high $R^{2}$ in both equations indicates a close relationship between seed yield and fertilizer rates. According to the equations, the best fertilizer rates of $\mathrm{SF}$ and CRF were 1802.12 and $1843.04 \mathrm{~kg} / \mathrm{hm}^{2}$, respectively, achieving the maximum yield (1839.24 and $2038.35 \mathrm{~kg} / \mathrm{hm}^{2}$, respectively) and net profit (5753.62 and $6500.16 \mathrm{CNY} / \mathrm{hm}^{2}$, respectively). CRF increased the maximum seed yield and net profit by $10.83 \%$ and $12.98 \%$, respectively, compared with SF. Therefore, the targeted use of CRF in red-yellow soil can increase seed yields and profitability.

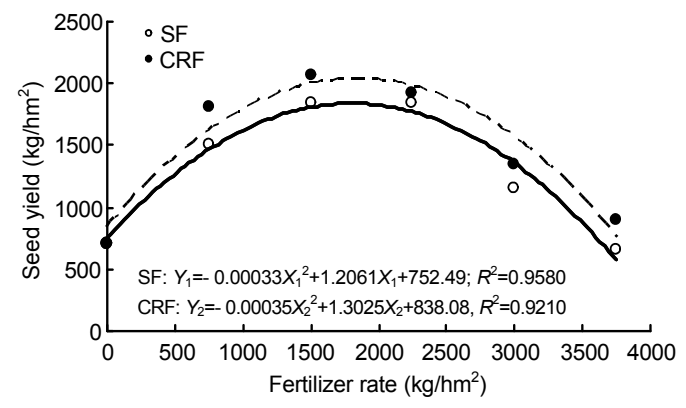

Fig. 1 Seed yield as a function applied of early ripening rapeseed

Table 2 Seed yield and fertilizer rate per kg yield of early ripening rapeseed using different fertilizer treatments

\begin{tabular}{|c|c|c|c|c|c|c|}
\hline \multirow{2}{*}{ Treatment } & \multicolumn{3}{|c|}{ Seed yield $\left(\mathrm{kg} / \mathrm{hm}^{2}\right)$} & \multicolumn{3}{|c|}{ Fertilizer rate per $\mathrm{kg}$ yield $(\mathrm{kg} / \mathrm{kg})$} \\
\hline & SF & CRF & Increase with SF (\%) & SF & CRF & Decrease by SF (\%) \\
\hline $\mathrm{CK}$ & \multicolumn{2}{|c|}{$708.97 \mathrm{fg}$} & & & & \\
\hline SF1/CRF1 & $664.63 \mathrm{~g}$ & $892.67 \mathrm{efg}$ & 34.31 & 5.642 & 4.201 & 25.55 \\
\hline $\mathrm{SF} 2 / \mathrm{CRF} 2$ & $1159.33 \mathrm{def}$ & $1346.47 \mathrm{cde}$ & 16.14 & 2.588 & 2.228 & 13.90 \\
\hline SF3/CRF3 & $1844.50 \mathrm{ab}$ & $1929.97 \mathrm{ab}$ & 4.63 & 1.220 & 1.166 & 4.43 \\
\hline SF4/CRF4 & $1839.40 \mathrm{ab}$ & $2066.97 \mathrm{a}$ & 12.37 & 0.815 & 0.726 & 11.01 \\
\hline SF5/CRF5 & $1513.93 \mathrm{bcd}$ & $1804.57 \mathrm{abc}$ & 19.20 & 0.495 & 0.416 & 16.11 \\
\hline
\end{tabular}

CK: no fertilizer; SF1/CRF1: $3750 \mathrm{~kg} / \mathrm{hm}^{2}$; SF2/CRF2: $3000 \mathrm{~kg} / \mathrm{hm}^{2} ; \mathrm{SF} 3 / \mathrm{CRF} 3: 2250 \mathrm{~kg} / \mathrm{hm}^{2} ; \mathrm{SF} 4 / \mathrm{CRF} 4: 1500 \mathrm{~kg} / \mathrm{hm}^{2} ; \mathrm{SF} 5 / \mathrm{CRF} 5$ : $750 \mathrm{~kg} / \mathrm{hm}^{2}$. The means denoted by different letters indicate significant differences among fertilization treatments $(P<0.05)$ 


\subsection{Oil yield}

Oil contents of rapeseed were not significantly affected by the various fertilizer applications $(P>0.05$; Table 3). The highest oil content appeared in the CK treatment $(42.88 \%)$. The oil contents of the SF and CRF treatments were relatively the same $(37.97 \%$ $41.62 \%$ and $38.77 \%-41.82 \%$, respectively). When the fertilizer rate increased, the oil content of the rapeseed gradually declined, namely higher fertilizer rates usually reduced the oil content. On the other hand, oil yield significantly varied with different fertilization treatments $(P<0.05)$. The trends of oil yields and seed yields were consistent, namely oil yield of low fertilizer rate treatments (CRF3, CRF4, and CRF5) were significantly higher than those of high fertilizer rate treatments (CRF1 and CRF2) $(P<0.05)$. CRF4 achieved maximum oil yield $\left(848.08 \mathrm{~kg} / \mathrm{hm}^{2}\right)$, followed by CRF3 $\left(776.43 \mathrm{~kg} / \mathrm{hm}^{2}\right)$ and the lowest oil yield was observed in SF1 $\left(252.36 \mathrm{~kg} / \mathrm{hm}^{2}\right)$. In addition, oil yields of CRF were significantly higher compared to SF by an average of $17.29 \%$.

\subsection{Yield components}

As shown in Table 4, there were statistical differences between SF and CRF in rapeseed at the mature stage for the plant height, first branch number, branch height, pod number, stem dry weight, and pod dry weight, but no significant differences for seed number per pod or 1000 -seed weight $(P>0.05)$. With the increase of the fertilizer rate, plant height, first branch number, branch height, pod number, stem dry weight, and pod dry weight were all shown as a trend of the first increase and then decrease. In combination with the SF, CRF applications reflected significant improvements of the rapeseed in first branch numbers $(4.63 \%)$, pod numbers $(12.32 \%)$, stem dry

Table 3 Oil content and oil yield of early ripening rapeseed using different fertilizer treatments

\begin{tabular}{|c|c|c|c|c|c|c|}
\hline \multirow{2}{*}{ Treatment } & \multicolumn{3}{|c|}{ Oil content $(\%)$} & \multicolumn{3}{|c|}{ Oil yield $\left(\mathrm{kg} / \mathrm{hm}^{2}\right)$} \\
\hline & $\mathrm{SF}$ & $\mathrm{CRF}$ & Increase with SF (\%) & $\mathrm{SF}$ & $\mathrm{CRF}$ & Increase with SF (\%) \\
\hline CK & \multicolumn{2}{|c|}{42.88} & \multicolumn{4}{|c|}{$304.00 \mathrm{~d}$} \\
\hline SF1/CRF1 & 37.97 & 38.77 & 2.11 & $252.36 \mathrm{~d}$ & $346.09 \mathrm{~d}$ & 37.14 \\
\hline SF2/CRF2 & 39.68 & 39.08 & -1.51 & $460.02 \mathrm{c}$ & $526.20 \mathrm{bc}$ & 14.39 \\
\hline SF3/CRF3 & 40.50 & 40.23 & -0.67 & $747.02 \mathrm{a}$ & $776.43 a$ & 3.94 \\
\hline SF4/CRF4 & 41.45 & 41.03 & -1.01 & $762.43 \mathrm{a}$ & $848.08 \mathrm{a}$ & 11.23 \\
\hline SF5/CRF5 & 41.62 & 41.82 & 0.48 & $630.10 \mathrm{~b}$ & $754.67 \mathrm{a}$ & 19.77 \\
\hline
\end{tabular}

SF1/CRF1: $3750 \mathrm{~kg} / \mathrm{hm}^{2} ; \mathrm{SF} 2 / \mathrm{CRF} 2: 3000 \mathrm{~kg} / \mathrm{hm}^{2} ; \mathrm{SF} 3 / \mathrm{CRF} 3: 2250 \mathrm{~kg} / \mathrm{hm}^{2}$; SF4/CRF4: $1500 \mathrm{~kg} / \mathrm{hm}^{2} ; \mathrm{SF} 5 / \mathrm{CRF} 5: 750 \mathrm{~kg} / \mathrm{hm}^{2} ; \mathrm{CK}: \mathrm{no}$ fertilizer. The means denoted by different letters indicate significant differences among fertilization treatments $(P<0.05)$

Table 4 Yield components of early rapeseed using different fertilizer treatments

\begin{tabular}{clllllllc}
\hline Treatment & $\begin{array}{c}\text { PH } \\
(\mathrm{cm})\end{array}$ & FBNP & $\begin{array}{c}\text { BH } \\
(\mathrm{cm})\end{array}$ & PNP & SNP & $\begin{array}{c}\text { TSW } \\
(\mathrm{g})\end{array}$ & $\begin{array}{c}\text { DWS } \\
(\mathrm{g} / \mathrm{plant})\end{array}$ & $\begin{array}{c}\text { DWP } \\
(\mathrm{g} / \mathrm{plant})\end{array}$ \\
\hline CK & $145.33 \mathrm{~d}$ & $3.60 \mathrm{c}$ & $90.47 \mathrm{ab}$ & $83.00 \mathrm{f}$ & $21.27 \mathrm{a}$ & $3.99 \mathrm{ab}$ & $7.96 \mathrm{~d}$ & $4.76 \mathrm{~d}$ \\
SF1 & $149.53 \mathrm{~cd}$ & $4.73 \mathrm{bc}$ & $74.53 \mathrm{~cd}$ & $127.67 \mathrm{def}$ & $21.65 \mathrm{a}$ & $3.91 \mathrm{ab}$ & $18.01 \mathrm{abc}$ & $9.31 \mathrm{bc}$ \\
SF2 & $167.73 \mathrm{ab}$ & $5.13 \mathrm{ab}$ & $90.93 \mathrm{ab}$ & $132.93 \mathrm{cdef}$ & $23.11 \mathrm{a}$ & $4.06 \mathrm{ab}$ & $16.91 \mathrm{bc}$ & $10.38 \mathrm{abc}$ \\
SF3 & $173.47 \mathrm{a}$ & $5.80 \mathrm{ab}$ & $87.40 \mathrm{abcd}$ & $194.34 \mathrm{ab}$ & $22.31 \mathrm{a}$ & $4.15 \mathrm{ab}$ & $19.85 \mathrm{abc}$ & $13.09 \mathrm{ab}$ \\
SF4 & $175.07 \mathrm{a}$ & $5.33 \mathrm{ab}$ & $83.47 \mathrm{abcd}$ & $208.10 \mathrm{a}$ & $23.21 \mathrm{a}$ & $4.08 \mathrm{~b}$ & $20.24 \mathrm{ab}$ & $11.69 \mathrm{abc}$ \\
SF5 & $162.00 \mathrm{~b}$ & $4.93 \mathrm{~b}$ & $89.07 \mathrm{abc}$ & $143.13 \mathrm{bcde}$ & $22.23 \mathrm{a}$ & $4.10 \mathrm{ab}$ & $15.03 \mathrm{c}$ & $9.67 \mathrm{abc}$ \\
CRF1 & $156.87 \mathrm{bc}$ & $5.20 \mathrm{ab}$ & $74.00 \mathrm{~d}$ & $167.07 \mathrm{abcde}$ & $21.05 \mathrm{a}$ & $3.90 \mathrm{ab}$ & $19.67 \mathrm{abc}$ & $11.22 \mathrm{abc}$ \\
CRF2 & $164.00 \mathrm{ab}$ & $4.93 \mathrm{~b}$ & $93.07 \mathrm{a}$ & $153.00 \mathrm{ef}$ & $23.52 \mathrm{a}$ & $4.28 \mathrm{ab}$ & $15.44 \mathrm{bc}$ & $8.97 \mathrm{c}$ \\
CRF3 & $167.67 \mathrm{ab}$ & $5.87 \mathrm{ab}$ & $85.93 \mathrm{abcd}$ & $196.07 \mathrm{abcd}$ & $23.71 \mathrm{a}$ & $4.26 \mathrm{ab}$ & $19.23 \mathrm{abc}$ & $12.77 \mathrm{abc}$ \\
CRF4 & $173.53 \mathrm{a}$ & $6.27 \mathrm{a}$ & $84.20 \mathrm{abcd}$ & $211.27 \mathrm{abc}$ & $23.91 \mathrm{a}$ & $4.17 \mathrm{ab}$ & $22.24 \mathrm{a}$ & $13.42 \mathrm{a}$ \\
CRF5 & $165.07 \mathrm{ab}$ & $5.87 \mathrm{~b}$ & $77.87 \mathrm{bcd}$ & $178.09 \mathrm{abcd}$ & $22.48 \mathrm{a}$ & $4.40 \mathrm{a}$ & $17.74 \mathrm{abc}$ & $10.46 \mathrm{abc}$ \\
\hline
\end{tabular}

PH: plant height; FBNP: first branch number per plant; BH: branch height; PNP: pod number per plant; SNP: seed number per pod; TSW: 1000-seed weight; DWS: dry weight of stem; DWP: dry weight of pod. SF1/CRF1: $3750 \mathrm{~kg} / \mathrm{hm}^{2}$; SF2/CRF2: $3000 \mathrm{~kg} / \mathrm{hm}^{2}$; SF3/CRF3: $2250 \mathrm{~kg} / \mathrm{hm}^{2}$; SF4/CRF4: $1500 \mathrm{~kg} / \mathrm{hm}^{2}$; SF5/CRF5: $750 \mathrm{~kg} / \mathrm{hm}^{2}$; CK: no fertilizer. The means denoted by different letters at the same column indicate significant differences among fertilization treatments $(P<0.05)$ 
weight $(4.76 \%)$, and pod dry weight $(4.96 \%)$, especially for the CRF4 treatment. Lodging is a common problem with rapeseed, and occurs primarily with taller varieties and under conditions of a higher soil $\mathrm{N}$ content (Ozer, 2003). Branch heights of SF were increased by an average of $2.43 \%$ compared to CRF caused by rapid nutrient release during the early growth stage, which made it easier for lodging to occur in the later stage.

Number of pods per plant is commonly a major determinant of rapeseed yield and this characteristic is dependent on the number of flowers produced by each plant. In this study, pod numbers showed a significant increase with seed yield (SF: $y=10.337 x-$ 243.49, $R^{2}=0.8098, P<0.05$; CRF: $y=10.736 x-310.51$, $R^{2}=0.7281, P<0.05$ ), as shown in Table 4. CRF4 achieved maximum pod numbers (211.27 per plant), and the lowest was observed in CK (83.00 per plant). SF1, SF2, SF3, SF4, and SF5 exhibited higher pod numbers than CK by $53.82 \%, 60.16 \%, 134.14 \%$, $150.72 \%$, and $72.45 \%$, respectively. In addition, CRF1, CRF2, CRF3, CRF4, and CRF5 were higher in pod numbers than CK by $101.29 \%, 84.34 \%, 136.23 \%$,
$154.54 \%$, and $114.57 \%$, respectively. It was shown that increasing the fertilizer rates usually caused larger increases in the pod numbers of rapeseed plants.

\section{$3.4 \mathrm{~N}$, P, and $\mathrm{K}$ uptakes}

There appeared to be an " $\mathrm{S}$ " shaped curve in the total dry matter accumulation (data not shown). The trends of nutrient accumulation and dry matter accumulation were basically consistent, which was suggested by the $\mathrm{N}$ and $\mathrm{P}$ accumulations during the different growth periods: flowering stage $>$ harvest time> wintering period (Fig. 2), while a relatively small increase was noted from the flowering stage to the harvest time, which appeared in the $\mathrm{K}$ accumulation. The $\mathrm{N}$ accumulation was significantly affected by the fertilizer rate $(P<0.05)$, while the $\mathrm{P}$ and $\mathrm{K}$ accumulation responses to the fertilizer rate were similar. Namely, increasing the fertilizer rates resulted in significantly higher $\mathrm{N}, \mathrm{P}$, and $\mathrm{K}$ accumulations in the rapeseed. The $\mathrm{N}, \mathrm{P}$, and $\mathrm{K}$ accumulations of CRF4 and SF3 in each group had outstanding performance during different growth periods.
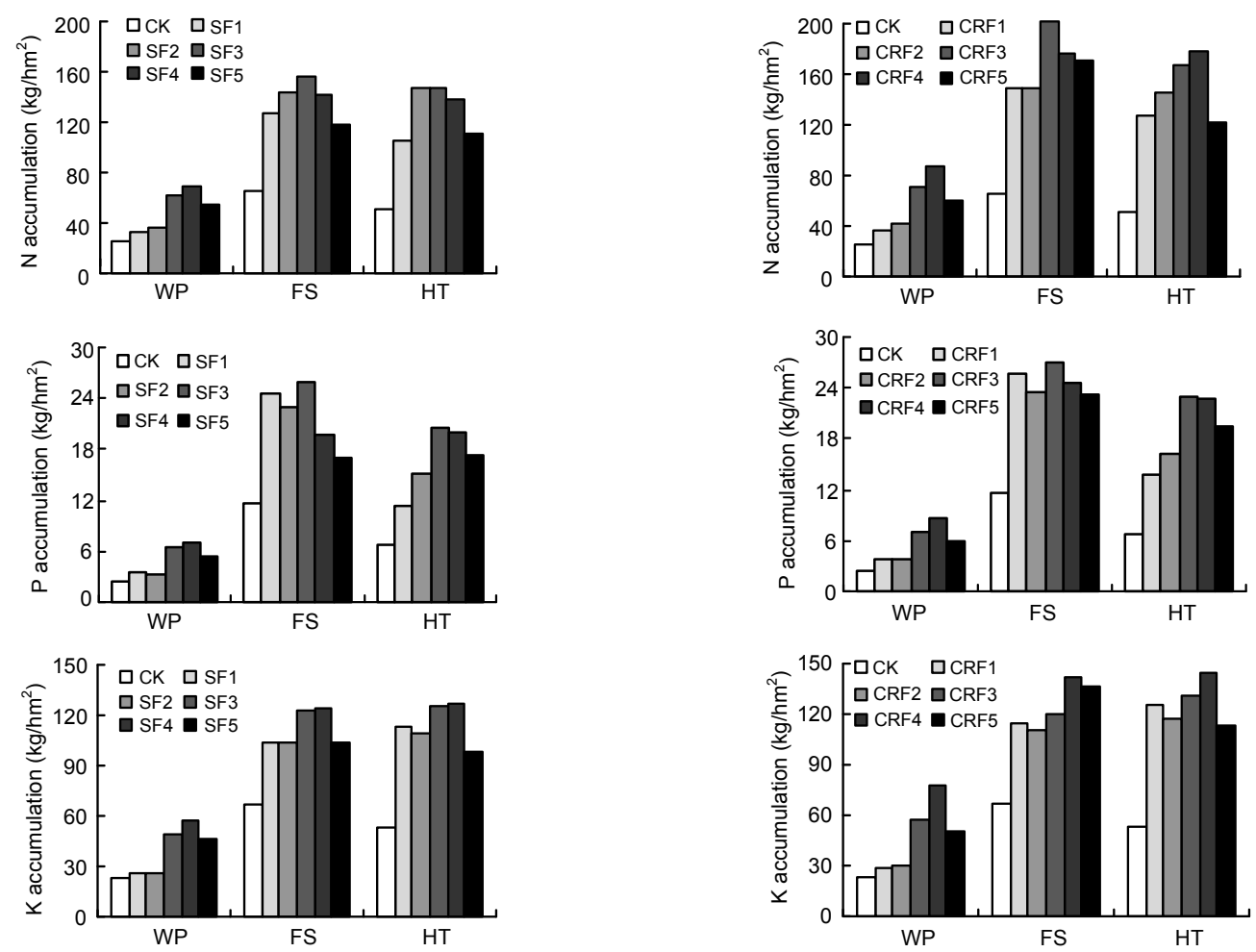

Fig. $2 \mathrm{~N}, \mathrm{P}$, and $\mathrm{K}$ accumulation of early ripening rapeseed using different fertilizer treatments $\mathrm{SF} 1 / \mathrm{CRF} 1: 3750 \mathrm{~kg} / \mathrm{hm}^{2}$; SF2/CRF2: $3000 \mathrm{~kg} / \mathrm{hm}^{2}$; SF3/CRF3: $2250 \mathrm{~kg} / \mathrm{hm}^{2}$; SF4/CRF4: $1500 \mathrm{~kg} / \mathrm{hm}^{2}$; SF5/CRF5: $750 \mathrm{~kg} / \mathrm{hm}^{2}$; CK: no fertilizer. WP: wintering period; FS: flowing stage; HT: harvest time 
According to Fig. 2, following the field application of $\mathrm{SF}$, the $\mathrm{N}$ accumulation rapidly increased during the first phase (i.e., the stage prior to flowering) and then slowly increased after the flowering stage. A one-off application of SF can lead to a large loss during the plant growth, which causes insufficient nutrient supply in the late stage (Liu et al., 2011). However, the $\mathrm{N}$ accumulation increased relatively constantly with the increased application of CRF throughout the growth period, and caused obvious delays in leaf senescence. At the flowering stage, the ranks of $\mathrm{N}$ accumulation among all treatments were CRF $3>$ CRF4 $>$ CRF $5>$ CRF $2>$ CRF 1 and SF3 $>$ SF4 $>$ SF2 $>$ SF $1>$ SF5. On the contrary, SF suffered from large $\mathrm{N}$ deficiencies at the flowering stage till harvest time.

At harvest time, nutrient accumulation first increased and then decreased with an increase in the fertilizer rate. The $\mathrm{N}, \mathrm{P}$, and $\mathrm{K}$ accumulations in $\mathrm{CRF}$ at harvest time were higher than those in SF by an average of $13.70 \%, 14.01 \%$, and $10.33 \%$, respectively. The SF suffered from nutrient deficiency at the flowering stage and at harvest time. CRF4 achieved maximum $\mathrm{N}$ accumulation $\left(177.76 \mathrm{~kg} / \mathrm{hm}^{2}\right)$ and the lowest was observed in SF1 $\left(105.96 \mathrm{~kg} / \mathrm{hm}^{2}\right)$. SF1, SF2, SF3, SF4, and SF5 were higher in N accumulation than $\mathrm{CK}$ by $109.78 \%, 192.16 \%, 193.33 \%$, $172.92 \%$, and $118.14 \%$, respectively. In addition, CRF1, CRF2, CRF3, CRF4, and CRF5 were higher in $\mathrm{N}$ accumulation than $\mathrm{CK}$ by $150.47 \%, 187.86 \%$,
$229.50 \%, 251.93 \%$, and $142.33 \%$, respectively. There was a significant relationship between the $\mathrm{N}$ accumulation at maturity and seed yield (SF: $y=9.9331 x+$ 129.57, $R^{2}=0.4868, P<0.05$; CRF: $y=10.122 x+127.25$, $\left.R^{2}=0.6515, P<0.05\right)$ as shown in Fig. 3. It indicated that increasing the $\mathrm{N}$ accumulation appeared to be a necessary procedure to maximize seed yield in rapeseed.

\subsection{N, P, and K usage efficiencies}

With the increase of the fertilizer rate, N, P, and $\mathrm{K}$ usage efficiencies had a downward trend, and N, $\mathrm{P}$, and $\mathrm{K}$ usage efficiencies of the CRF were increased by an average of $9.74,2.28$, and 8.18 percentage points, respectively, compared to SF (Table 5). CRF5 received the highest NUE (79.88\%), followed by CRF4 (70.69\%), while the lowest NUE was observed for SF1 (12.28\%). Under the same fertilizer rate, CRF1, CRF2, CRF3, CRF4, and CRF5 increased

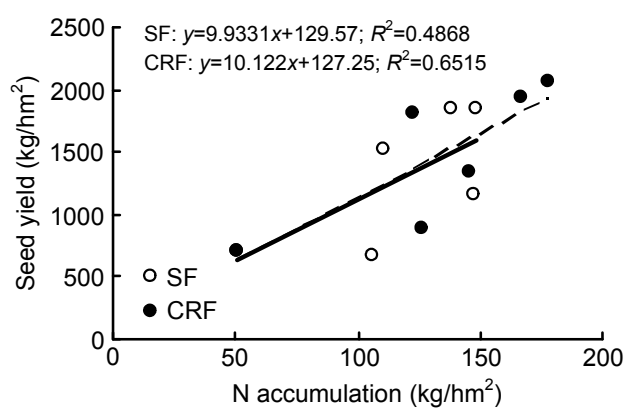

Fig. $3 \mathrm{~N}$ accumulation as a function applied of early ripening rapeseed

Table $5 \mathrm{~N}$, P, and $\mathrm{K}$ usage efficiencies, translocation amounts, translocation rates, contribution rates, and harvest indexes of early ripening rapeseed using different fertilizer treatments

\begin{tabular}{cccccccccccccccc}
\hline Treat. & $\begin{array}{c}\text { NTA } \\
\left(\mathrm{kg} / \mathrm{hm}^{2}\right)\end{array}$ & $\begin{array}{c}\text { NTR } \\
(\%)\end{array}$ & $\begin{array}{c}\text { NCR } \\
(\%)\end{array}$ & $\begin{array}{c}\text { NHI } \\
(\%)\end{array}$ & $\begin{array}{c}\text { NUE } \\
(\%)\end{array}$ & $\begin{array}{c}\text { PTA } \\
\left(\mathrm{kg} / \mathrm{hm}^{2}\right)\end{array}$ & $\begin{array}{c}\text { PTR } \\
(\%)\end{array}$ & $\begin{array}{c}\text { PCR } \\
(\%)\end{array}$ & $\begin{array}{c}\text { PHI } \\
(\%)\end{array}$ & $\begin{array}{c}\text { PUE } \\
(\%)\end{array}$ & $\begin{array}{c}\text { KTA } \\
\left(\mathrm{kg} / \mathrm{hm}^{2}\right)\end{array}$ & $\begin{array}{c}\text { KTR } \\
(\%)\end{array}$ & $\begin{array}{c}\text { KCR } \\
(\%)\end{array}$ & $\begin{array}{c}\text { KHI } \\
(\%)\end{array}$ & $\begin{array}{c}\text { KUE } \\
(\%)\end{array}$ \\
\hline CK & 21.90 & 63.92 & 57.40 & 52.21 & & 5.55 & 93.91 & 87.96 & 91.45 & & 19.83 & 38.89 & 88.29 & 7.53 & \\
SF1 & 38.40 & 46.97 & 61.54 & 26.52 & 12.28 & 12.95 & 79.99 & 159.29 & 56.73 & 2.09 & 15.71 & 17.97 & 37.45 & 3.91 & 20.02 \\
SF2 & 40.70 & 45.72 & 41.01 & 34.02 & 26.96 & 10.21 & 74.91 & 87.94 & 64.80 & 4.65 & 20.56 & 25.01 & 42.99 & 6.99 & 23.27 \\
SF3 & 58.66 & 62.44 & 51.97 & 50.55 & 36.17 & 11.24 & 80.75 & 62.72 & 76.99 & 10.33 & 28.73 & 30.58 & 48.12 & 8.41 & 39.61 \\
SF4 & 52.04 & 59.43 & 50.86 & 53.24 & 48.52 & 7.00 & 71.94 & 40.23 & 78.59 & 14.97 & 26.15 & 27.29 & 46.06 & 8.29 & 60.71 \\
SF5 & 43.78 & 64.58 & 50.81 & 55.10 & 66.29 & 5.16 & 68.53 & 34.42 & 77.59 & 23.79 & 25.74 & 32.79 & 56.83 & 9.58 & 74.07 \\
CRF1 & 49.51 & 48.67 & 66.64 & 29.99 & 16.89 & 13.42 & 79.13 & 131.18 & 59.62 & 3.16 & 21.62 & 22.63 & 41.43 & 4.74 & 24.16 \\
CRF2 & 51.59 & 52.28 & 52.48 & 38.25 & 28.53 & 11.79 & 81.09 & 86.69 & 74.13 & 5.38 & 26.00 & 28.65 & 49.75 & 6.91 & 26.42 \\
CRF3 & 79.69 & 65.04 & 64.48 & 47.09 & 42.93 & 11.01 & 80.90 & 53.71 & 79.35 & 12.18 & 21.85 & 24.69 & 33.84 & 8.83 & 43.11 \\
CRF4 & 70.35 & 62.05 & 52.22 & 46.75 & 70.69 & 9.84 & 79.74 & 48.43 & 82.43 & 17.96 & 28.80 & 26.22 & 45.63 & 8.17 & 75.48 \\
CRF5 & 74.14 & 72.63 & 78.48 & 60.44 & 79.88 & 8.49 & 78.03 & 47.43 & 83.59 & 28.54 & 40.18 & 38.77 & 80.73 & 9.25 & 89.42 \\
\hline
\end{tabular}

Treat.: treatment; SF1/CRF1: $3750 \mathrm{~kg} / \mathrm{hm}^{2}$; SF2/CRF2: $3000 \mathrm{~kg} / \mathrm{hm}^{2}$; SF3/CRF3: $2250 \mathrm{~kg} / \mathrm{hm}^{2}$; SF4/CRF4: $1500 \mathrm{~kg} / \mathrm{hm}^{2}$; SF5/CRF5: $750 \mathrm{~kg} / \mathrm{hm}^{2}$; CK: no fertilizer. NTA, PTA, KTA: N, P, K translocation amount; NTR, PTR, KTR: N, P, K translocation rate; NCR, PCR, KCR: N, P, K contribution rate; NHI, PHI, KHI: N, P, K harvest index; NUE, PUE, KUE: N, P, K usage efficiency 
in NUE by $4.61,1.57,6.76,22.17$, and 13.59 percentage points compared with SF1, SF2, SF3, SF4, and SF5, respectively. On the other hand, the trends of $\mathrm{P}, \mathrm{K}$, and $\mathrm{N}$ usage efficiencies were consistent at maturity. $\mathrm{P}$ usage efficiency was in the range of $2.09 \%-23.79 \%$ for $\mathrm{SF}$ and $3.16 \%-28.54 \%$ for $\mathrm{CRF}$, while $\mathrm{K}$ usage efficiency was in the range of $20.02 \%$ $74.07 \%$ for SF and $24.16 \%-89.42 \%$ for CRF. Therefore, CRF could significantly improve FUE for early ripening rapeseed and reduce the loss of nutrient Corresponding increases in N, P, and $\mathrm{K}$ harvest index were observed with using CRF compared to SF and the values were increased with increasing the fertilizer rate.

The differences of the $\mathrm{N}, \mathrm{P}$, and $\mathrm{K}$ translocation rates and the $\mathrm{N}, \mathrm{P}$, and $\mathrm{K}$ contribution rates in each fertilization treatment were relatively small, while the $\mathrm{P}$ contribution rate showed a statistical decline trend with decreasing the fertilizer rate between CRF and $\mathrm{SF}$, suggesting that the $\mathrm{P}$ accumulation of the rapeseed plant was caused more by the absorption of the exogenous $\mathrm{P}$ supplied. The $\mathrm{N}$ accumulation of CRF in rapeseed at the seedling stage accounted for an average of $62.86 \%$ of the total $\mathrm{N}$ accumulation throughout the growing season, while the corresponding proportion was higher than that of SF by 11.62 percentage points for plants. CRF3 achieved its maximum $\mathrm{N}$ translocation amount $\left(79.69 \mathrm{~kg} / \mathrm{hm}^{2}\right)$. $\mathrm{SF} 1, \mathrm{SF} 2, \mathrm{SF} 3, \mathrm{SF} 4$, and SF5 were higher in the N translocation amount than CK by $75.34 \%, 85.84 \%$, $167.85 \%, 137.63 \%$, and $99.91 \%$, respectively. In addition, CRF1, CRF2, CRF3, CRF4, and CRF5 were higher in $\mathrm{N}$ translocation amount than $\mathrm{CK}$ by $126.07 \%, 135.57 \%, 263.88 \%, 221.23 \%$, and $238.54 \%$. Consequently, the $\mathrm{N}$ supply to the pods was achieved primarily by $\mathrm{N}$ mobilization from the vegetative parts.

\section{Discussion}

\subsection{Optimum application rates for CRF in the field}

The application of slow and controlled release fertilizers reduces environmental pollution in terms of hazardous gaseous emissions and water eutrophication (Azeem et al., 2014) and simultaneously enhances FUE which is an important presupposition for the increased production profit (Gaju et al., 2011).
Due to its relatively high price compared with SF, use of CRF may be limited unless its use is practical, profitable, and reduces the environmental $\mathrm{N}$ loss (Noellsch et al., 2009; Zebarth et al., 2009). In practice, the use of slow and controlled release fertilizers and/or stabilized fertilizers is primarily increased in greenhouses, golf courses, and professional lawn management, as well as by consumers (home and garden) and landscape gardeners (Arrobas et al., 2011).

Even if CRF use becomes economical, the widespread acceptance by growers will likely be limited as a result of grower concern about field performance. Some researches for increasing rice (Oryza sativa L.) yield by a single basal application of CRF were attributed to a greater soil available $\mathrm{N}$ supply, superior development of root systems, better nutrient absorption capacity, slower senescence, and enhancements of lodging resistance at the later stages (Carreres et al., 2003; Tang et al., 2007). Therefore, choosing the appropriate application rate for rapeseed is critical for the successful field application of CRF.

In this present study, with the increasing of the fertilizer rate, the seed yield of rapeseed first increased and then decreased. The application of CRF for seed yield got more than that of SF by an average of $17.33 \%$ with a lower fertilizer rate per $\mathrm{kg}$ yield by an average of $14.2 \%$ (Table 2). CRF4 achieved the highest yield $\left(2066.97 \mathrm{~kg} / \mathrm{hm}^{2}\right)$, followed by CRF3 $\left(1929.97 \mathrm{~kg} / \mathrm{hm}^{2}\right)$. Seed profit for CRF was significantly higher than that for SF (Table 2). CRF4 achieved the highest profit rate, $7126.4 \mathrm{CNY} / \mathrm{hm}^{2}$, followed by CRF5 $\left(7033.1 \mathrm{CNY} / \mathrm{hm}^{2}\right)$. Compared with SF4, CRF4 increased by $12.37 \%$ in seed yield and decreased the fertilizer rate per $\mathrm{kg}$ yield by $11.01 \%$. According to the regression equations of the fertilizer rate on seed yield, the best fertilizer rates for $\mathrm{SF}$ and CRF were 1802.12 and $1843.04 \mathrm{~kg} / \mathrm{hm}^{2}$, respectively, achieving maximum yield (1839.24 and $2038.35 \mathrm{~kg} / \mathrm{hm}^{2}$, respectively), and net profit (5753.62 and $6500.16 \mathrm{CNY} / \mathrm{hm}^{2}$, respectively). Thus, a rate of $1500 \mathrm{~kg} / \mathrm{hm}^{2}$ in CRF has been shown to be adequate for early ripening rapeseed production.

\subsection{Yield components of CRF and SF}

$\mathrm{N}$ increases its yield by influencing a number of growth parameters such as branches per plant and flowers per plant and by producing more vigorous growth and development. It has been well documented 
that increasing the $\mathrm{N}$ rates produces more lodged plants (Ozer, 2003). This obviously has an indirect effect since high $\mathrm{N}$ rates promote the formation of more pods and seeds but also decrease in stem stability. Cheema et al. (2001) also showed that the number of pods per plant increased with increasing rates of $\mathrm{N}$. CRF can significantly increase pod numbers and seed yield, while improving the ratio of seed/stem ( $\mathrm{Yu}$ et al., 2012). Wang et al. (2013) showed that the coated fertilizer or CRF not only increased the seed yield of rapeseed, but led to effective pod numbers, seed numbers per pod, 1000-seed weight and FUE, and in addition, also improved the resistance to cold, disease, and lodging of rapeseed.

In this present study, the yield differences measured for CRF and SF were primarily due to the changes in first branch numbers, pod numbers, stem dry weight, and pod dry weight. The results also revealed that the number of pods increased with an increase in the applied fertilizer rate, and the major cause of reduced yields in SF is decrease in the number of pods per plant. The pod number reflects a significant increase with the seed yield (SF: $R^{2}=$ 0.8098; CRF: $R^{2}=0.7281$ ). Compared with SF, although farmers like using fertilizer which costs less, CRF can achieve a greater profit, and is attributed to increased soil availability of $\mathrm{N}$ (data not shown), superior development of the root systems, better nutrient absorption capacity, delayed senescence, and enhanced lodging resistance.

\subsection{Improvement of FUE by CRF}

FUE has become a critical measure of sustainable agriculture. A successful plant growth supported by a high $\mathrm{N}$ uptake rate will be decisive for reaching high seed yield (Barłóg and Grzebisz, 2004). There was a close and positive relationship between nutrient uptake and seed yield, especially in N. N fertilization treatment may significantly affect the strategy of rapeseed plants adaptation to $\mathrm{N}$ availability. A successful plant growth supported by a high $\mathrm{N}$ uptake rate will be decisive for reaching high seed yield (Barłóg and Grzebisz, 2004), but it frequently leads to reduction of NUE after the increasing of the $\mathrm{N}$ uptake. Higher NUE is an important prerequisite for increased profitability, either through greater yields or reduced N losses (Liu et al., 2008; Gaju et al., 2011). Malagoli et al. (2005a) showed that the $\mathrm{N}$ require- ments for seed filling were satisfied primarily by $\mathrm{N}$ mobilized from vegetative parts (about $73 \%$ of the total $\mathrm{N}$ in pods). The mobilization of endogenous $\mathrm{N}$ from these leaves was prolonged and concomitant with $\mathrm{N}$ accumulation in the pods. How to promote $\mathrm{N}$ transport from the vegetative organs to seed in the late growing stage and improve $\mathrm{N}$ seed physiological efficiency, so as to achieve the unity of high yield and high NUE of rapeseed on the basis of a certain amount of $\mathrm{N}$ uptake, is becoming a hot issue of current research.

In this present study, there was a significant relationship identified between $\mathrm{N}$ accumulation at maturity and seed yield (SF: $R^{2}=0.4868$; CRF: $R^{2}=0.6515$ ). It was noted that NUE, post-heading $\mathrm{N}$ uptake, the contribution of $\mathrm{N}$ translocation to the total $\mathrm{N}$ in the seed, the partial factor productivity of $\mathrm{N}$ as well as seed yield were significantly influenced by CRF. After the flowering stage, $\mathrm{N}$ translocation and remobilization of different organs became the major metabolism, rather than $\mathrm{N}$ absorption by the entire plant (Zuo et al., 2014). At maturity, dry matter, nutrient uptake, and their harvest indexes of rapeseed plants varied among the different fertilization treatments, with a significant fertilization being identified with all these parameters. Prolonged $\mathrm{N}$ uptake from the soil with CRF resulted in delayed plant senescence. $\mathrm{N}$ requirements for seed filling were satisfied primarily by $\mathrm{N}$ mobilized from vegetative parts of CRF (average of $62.86 \%$ for the total $\mathrm{N}$ in the pods), and the endogenous $\mathrm{N}$ flow showed that there was a net transfer of $\mathrm{N}$ to the pods by the stem and leaves.

With increasing the fertilizer rate, $\mathrm{N}$ accumulation increased and $\mathrm{N}$ harvest index gradually reduced. The proportion of $\mathrm{N}$ accumulated in seeds at the flowering stage compared to the total $\mathrm{N}$ at maturity increased gradually. Under high $\mathrm{N}$ fertilization, the $\mathrm{N}$ harvest index became less, indicating that the appropriate amount of $\mathrm{N}$ fertilizer can promote nutrients transporting from other organs of the plant to seed, while further increasing $\mathrm{N}$ being only limited by the seed capacity of the plant itself makes it hard for the output of nutrient accumulation in vegetative organs, which leads to the harvest index decreasing. Furthermore, the NUE of different fertilizer rates for CRF was significantly higher than that for SF $(P<0.05)$. These results suggest that the CRF used in this study was effective for the agricultural production 
of rapeseed, and also indicate that the CRF4 treatment corresponded to the optimum application rate of $\mathrm{CRF}$ for the rapeseed fields studied in southern China.

\section{Conclusions}

In this study, a single basal application of CRF obviously contributed to a greater supply of soil available $\mathrm{N}$, thus creating a suitable nutritional environment for vigorous growth of rapeseed. Seed yield of early ripening rapeseed was significantly higher for CRF treatments than for SF treatments, while no significant differences in seed yield were found between CRF/SF $\left(3750 \mathrm{~kg} / \mathrm{hm}^{2}\right)$ and CK. These results indicated that $1500 \mathrm{~kg} / \mathrm{hm}^{2}$ was the optimum application rate for $\mathrm{CRF} / \mathrm{SF}$ in rapeseed fields in southern China. CRF and the abilities of N, P, and K fertilizer applied to improve $\mathrm{N}, \mathrm{P}$, and $\mathrm{K}$ usage efficiencies resulted in increased seed yield as well as the expected environmental and economic benefits. In addition, the yield increases afforded by CRF were partly due to higher nutrient accumulation and FUE. It is necessary to determine the effects of the frequency and timing of CRF applications on rapeseed in the future.

\section{Compliance with ethics guidelines}

Chang TIAN, Xuan ZHOU, Qiang LIU, Jian-wei PENG, Wen-ming WANG, Zhen-hua ZHANG, Yong YANG, Hai-xing SONG, and Chun-yun GUAN declare that they have no conflict of interest.

This article does not contain any studies with human or animal subjects performed by any of the authors.

\section{References}

Arrobas, M., Parada, M.J., Magalhães, P., et al., 2011. Nitrogen-use efficiency and economic efficiency of slowrelease $\mathrm{N}$ fertilisers applied to irrigated turfs in a mediterranean environment. Nutr. Cycl. Agroecosys., 89(3): 329-339.

http://dx.doi.org/10.1007/s10705-010-9397-x

Azeem, B., KuShaari, K.Z., Man, Z.B., et al., 2014. Review on materials \& methods to produce controlled release coated urea fertilizer. J. Control. Release, 181:11-21. http://dx.doi.org/10.1016/j.jconrel.2014.02.020

Bao, S.D., 2005. Soil and Agricultural Chemistry Analysis, 3rd Ed. China Agriculture Press, Beijing, China (in Chinese).

Barłóg, P., Grzebisz, W., 2004. Effect of timing and nitrogen fertilizer application on winter oilseed rape (Brassica napus L.). II. Nitrogen uptake dynamics and fertilizer efficiency. J. Agron. Crop Sci., 190(5):314-323. http://dx.doi.org/10.1111/j.1439-037X.2004.00109.x

Carreres, R., Sendra, J., Ballesteros, R., et al., 2003. Assessment of slow release fertilizers and nitrification inhibitors in flooded rice. Biol. Fert. Soils, 39(2):80-87. http://dx.doi.org/10.1007/s00374-003-0684-4

Cheema, M.A., Malik, M.A., Hussain, A., et al., 2001. Effects of time and rate of nitrogen and phosphorus application on the growth and the seed and oil yields of canola (Brassica napus L.). J. Agron. Crop Sci., 186(2):103-110. http://dx.doi.org/10.1046/j.1439-037X.2001.00463.x

Dai, J.J., Fan, X.L., Yu, J.G., et al., 2008. Study on the rapid method to predict longevity of controlled release fertilizer coated by water soluble resin. Agric. Sci. China, 7(9): 1127-1132. http://dx.doi.org/10.1016/S1671-2927(08)60155-8

Dordas, C., 2009. Dry matter, nitrogen and phosphorus accumulation, partitioning and remobilization as affected by $\mathrm{N}$ and $\mathrm{P}$ fertilization and source-sink relations. Eur. J. Agron., 30(2):129-139. http://dx.doi.org/10.1016/j.eja.2008.09.001

Du, C., Tang, D., Zhou, J., et al., 2008. Prediction of nitrate release from polymer-coated fertilizers using an artificial neural network model. Biosyst. Eng., 99(4):478-486. http://dx.doi.org/10.1016/j.biosystemseng.2007.12.003

Gaju, O., Allard, V., Martre, P., et al., 2011. Identification of traits to improve the nitrogen-use efficiency of wheat genotypes. Field Crops Res., 123(2):139-152. http://dx.doi.org/10.1016/j.fcr.2011.05.010

Goulding, K., Jarvis, S., Whitmore, A., 2008. Optimizing nutrient management for farm systems. Philos. Trans. $R$. Soc. B, 363(1491):667-680. http://dx.doi.org/10.1098/rstb.2007.2177

Guan, C.Y., 2006. The cultivation pattern change of winter rapeseed to increase and develop production. Chin. J. Oil Crop Sci., 28(1):83-85 (in Chinese).

Hussain, N., Hui, L.I., Jiang, Y.X., et al., 2014. Response of seed tocopherols in oilseed rape to nitrogen fertilizer sources and application rates. J. Zhejiang Univ.-Sci. B (Biomed. \& Biotechnol.), 15(2):181-193. http://dx.doi.org/10.1631/jzus.B1300036

Ju, X., Liu, X., Zhang, F., et al., 2004. Nitrogen fertilization, soil nitrate accumulation, and policy recommendations in several agricultural regions of China. AMBIO: J. Hum. Environ., 33(6):300-305. http://dx.doi.org/10.1579/0044-7447-33.6.300

Kaplan, L., Tlustoš, P., Száková, J., et al., 2013. The influence of slow-release fertilizers on potted chrysanthemum growth and nutrient consumption. Plant Soil Environ., 59(9):385-391.

Li, Q.S., Wu, S., Ru, T.J., et al., 2012. Synthesis and performance of polyurethane coated urea as slow/controlled release fertilizer. J. Wuhan Univ. Technol., 27(1):126-129. http://dx.doi.org/10.1007/s11595-012-0421-7 
Liu, Q., Song, H.X., Rong, X.M., et al., 2008. Differences in nitrogen use efficiency among different rape varieties and their physiological basis. J. Plant Nutr. Fert., 14(1): 113-119 (in Chinese).

Liu, X.W., Lu, J.W., Li, X.K., et al., 2011. Dry matter accumulation and $\mathrm{N}, \mathrm{P}, \mathrm{K}$ absorbtion and utilization in direct seeding winter oilseed (Brassica napus L.). China Agric. Sci., 44(23):4823-4832 (in Chinese). http://dx.doi.org/10.3864/j.issn.0578-1752.2011.23.008

Malagoli, P., Laine, P., Rossato, L., et al., 2005a. Dynamics of nitrogen uptake and mobilization in field-grown winter oilseed rape (Brassica napus) from stem extension to harvest: I. Global $\mathrm{N}$ flows between vegetative and reproductive tissues in relation to leaf fall and their residual N. Ann. Bot., 95(5):853-861. http://dx.doi.org/10.1093/aob/mci091

Malagoli, P., Laine, P., Rossato, L., et al., 2005b. Dynamics of nitrogen uptake and mobilization in field-grown winter oilseed rape (Brassica napus) from stem extension to harvest: II. An ${ }^{15} \mathrm{~N}$-labelling-based simulation model of $\mathrm{N}$ partitioning between vegetative and reproductive tissues. Ann. Bot., 95(7):1187-1198.

http://dx.doi.org/10.1093/aob/mci131

Ni, B., Liu, M., Lü, S., 2009. Multifunctional slow-release urea fertilizer from ethylcellulose and superabsorbent coated formulations. Chem. Eng. J., 155(3):892-898. http://dx.doi.org/10.1016/j.cej.2009.08.025

Noellsch, A.J., Motavalli, P.P., Nelson, K.A., et al., 2009. Corn response to conventional and slow-release nitrogen fertilizers across a claypan landscape. Agron. J., 101(3):607-614. http://dx.doi.org/10.2134/agronj2008.0067x

Ozer, H., 2003. Sowing date and nitrogen rate effects on growth, yield and yield components of two summer rapeseed cultivars. Eur. J. Agron., 19(3):453-463. http://dx.doi.org/10.1016/S1161-0301(02)00136-3

Tang, S.H., Yang, S.H., Chen, J.S., et al., 2007. Studies on the mechanism of single basal application of controlledrelease fertilizers for increasing yield of rice (Oryza sativa L.). Agric. Sci. China, 6(5):586-596 (in Chinese). http://dx.doi.org/10.1016/S1671-2927(07)60087-X

Wang, R.F., An, D.G., Hu, C.S., et al., 2011. Relationship between nitrogen uptake and use efficiency of winter wheat grown in the north China plain. Crop Pasture Sci., 62(6):504-514.

http://dx.doi.org/10.1071/CP10383

Wang, S.P., Li, X.K., Lu, J.W., et al., 2013. Effects of combined application of urea and controlled-release urea on yield, profits of rapeseed and soil inorganic nitrogen. Chin. J. Oil Crop Sci., 35(3):295-300 (in Chinese). http://dx.doi.org/10.7505/j.issn.1007-9084.2013.03.011

Yan, X., Jin, J.Y., Ping, H.E., et al., 2008. Recent advances on the technologies to increase fertilizer use efficiency. Agric. Sci. China, 7(4):469-479 (in Chinese). http://dx.doi.org/10.1016/S1671-2927(08)60091-7

Yu, C.B., Xie, L.H., Hu, X.J., et al., 2012. Simplified applica- tion technique of nitrogen fertilizer on rapeseed. Chin. J. Oil Crop Sci., 2012, 34(6):633-637 (in Chinese).

Zebarth, B.J., Drury, C.F., Tremblay, N., et al., 2009. Opportunities for improved fertilizer nitrogen management in production of arable crops in eastern Canada: a review. Can. J. Soil Sci., 89(2):113-132. http://dx.doi.org/10.4141/CJSS07102

Zhao, B., Dong, S., Zhang, J., et al., 2013. Effects of controlledrelease fertiliser on nitrogen use efficiency in summer maize. PLOS ONE, 8(8):e70569. http://dx.doi.org/10.1371/journal.pone.0070569

Zhu, Z.L., Chen, D.L., 2002. Nitrogen fertilizer use in Chinacontributions to food production, impacts on the environment and best management strategies. Nutr. Cycl. Agroecosys., 63(2):117-127. http://dx.doi.org/10.1023/A:1021107026067

Zuo, Q.S., Yang, H.Y., Leng, S.H., et al., 2014. Effects of nitrogen fertilizer on nitrogen accumulation, translocation and nitrogen use efficiency in rapeseed (Brassica napus L.). Acta Agron. Sin., 40(3):511-518 (in Chinese).

\section{中文概要}

\section{题 目: 控释肥料对早熟油菜产量、养分吸收和肥料利用 率的影响}

目 的: 氮 $(\mathrm{N})$ 、磷 $(\mathrm{P})$ 和钾 $(\mathrm{K})$ 是作物生长发育所 必需的营养元素。然而, 过度地投入会导致田间 低效的利用率，造成大量养分损失，影响土壤、 水和大气的质量, 以及人类健康和生物多样性。 因此, 本实验研究控释肥料 (CRF) 是否可以替 代可溶性肥料（SF）, 有效地增加作物产量, 提 高肥料利用率，减少田间养分损失。

创新点: 连续 2 年（2011 2013 年）在中国南方红黄壤地 区开展田间试验, 研究控释肥料对早熟油菜 (湘 杂油 1613）的产量、生长、养分吸收和肥料利用 率的影响。可更好地解决稻-稻一油生产过程中的 季节矛盾, 简化油菜生产模式, 增加农民收入, 并确保国家粮油安全。

方 法: 设置 $\mathrm{SF}$ 和等量 $\mathrm{CRF}$ 五个施用量处理, 即 $\mathrm{SF} 1 / \mathrm{CRF} 1$ $\left(3750 \mathrm{~kg} / \mathrm{hm}^{2}\right) 、 \mathrm{SF} 2 / \mathrm{CRF} 2\left(3000 \mathrm{~kg} / \mathrm{hm}^{2}\right) 、 \mathrm{SF} 3 /$ CRF3 $\left(2250 \mathrm{~kg} / \mathrm{hm}^{2}\right) 、 \mathrm{SF} 4 / \mathrm{CRF} 4\left(1500 \mathrm{~kg} / \mathrm{hm}^{2}\right)$ 和 $\mathrm{SF} 5 / \mathrm{CRF} 5\left(750 \mathrm{~kg} / \mathrm{hm}^{2}\right)$, 以及不施肥处理 (CK)。

结 论: $\mathrm{CRF}$ 处理油菜产量较 $\mathrm{SF}$ 处理两年平均提高 $14.51 \%$, 其中 CRF4 和 SF3 处理获得最大产量 (2066.97 和 $1844.50 \mathrm{~kg} / \mathrm{hm}^{2}$ ), 其次是 CRF3 处理 $\left(1929.97 \mathrm{~kg} / \mathrm{hm}^{2}\right)$ 和 SF4 处理 $\left(1839.40 \mathrm{~kg} / \mathrm{hm}^{2}\right)$ 。 此外, CRF4 处理利润最高 (人民币 7126.4 元每 公顷), 与 SF4 处理相比, 其油菜产量增加 $12.37 \%$ 
和单位肥料施用量下降 $11.01 \%$ 。较 SF 处理, CRF 处理显著增加油菜分支数、角果数和干物质重量 $(P<0.05)$ 。单株角果数是油菜产量构成的主要 因素。随着肥料施用量的增加, $\mathrm{N} 、 \mathrm{P}$ 和 $\mathrm{K}$ 吸收 量先增加后下降, 而 $\mathrm{N} 、 \mathrm{P}$ 和 $\mathrm{K}$ 利用率均降低。 同时, $\mathrm{CRF}$ 处理的 $\mathrm{N} 、 \mathrm{P} 、 \mathrm{~K}$ 吸收量和 $\mathrm{N} 、 \mathrm{P} 、 \mathrm{~K}$ 利用率显著高于 $\mathrm{SF}$ 处理的结果 $(P<0.05)$ 。 $\mathrm{CRF}$
处理 $\mathrm{N}$ 素累积量和 $\mathrm{N}$ 素利用率较 $\mathrm{SF}$ 处理平均提 高 13.66\%和 9.74 个百分点。总之, CRF一次性基 施显著促进油菜的生长发育, 通过提供后期生长 阶段足够的养分, 最终减少了土壤中的养分残余 和增加了植株的养分积累, 提高了肥料利用率。

关键词: 早熟油菜; 控释肥料; 产量; 养分吸收; 肥料利 用率 